\title{
Methodological Notes on Modelling Reconstructions After Literary Architecture
}

\author{
Fabio Colonnese ${ }^{1}$ (D)
}

Accepted: 28 May 2021 / Published online: 10 June 2021

(c) The Author(s) 2021

\begin{abstract}
The manifold relationships between text and image are investigated by analysing attempts at a three-dimensional reconstruction of the Palace of Love and Venus described in Giovan Battista Marino's Adonis. From text analysis and iconographical precedents to free-hand sketching and three-dimensional modelling, the article describes the progressive translation of some verses of the poem into a consistent system of drawings and models, which, besides revealing some hidden features of text, addresses the implicit limits of the ineffable quality of Marino's literary space.
\end{abstract}

Keywords Literary space - Giovan Battista Marino · Adone - Textual interpretation · Modelling $\cdot$ Reconstruction

\section{Introduction}

This article analyses the practice of reconstructing architecture described in literature and, by focusing on the case studio of Giovan Battista Marino's Adone, it provides a methodological framework and a discussion of primary and secondary results. At the same time, it explores the limits and paradoxes of this practice when it is applied to literary spaces that are apparently defined but reveal themselves to be ineffable, out of reach of a scientific representation.

In this context, modelling-or the construction of a graphic device analogous to the described spatial situation-originates from the mental experience of the literary space and can be framed within the operative field of Virtual Heritage. A framework for scientific and cultural visualization, Virtual Heritage is aimed at the knowledge, preservation, and dissemination of tangible or intangible heritage and is mainly intended as a visual re-creation of a cultural expression, site, or environment from the past, generally through two and three-dimensional modelling, digital collages, photo-montages, animation, panoramic photographs, laser-scan modelling,

Fabio Colonnese

fabio.colonnese@uniroma1.it

1 Dept. History, Drawing, and Restoration of Architecture, Sapienza University, Rome, Italy 
photo-modelling, augmented reality, or immersive virtual reality (Cameron and Kenderdine 2007; Kalay et al. 2007). A deeper understanding of specific cultural expressions and devices may involve the investigation of the images 'hidden' inside the writings, disclosing of a wealth of forms and meanings in a description. In this sense, Virtual Heritage promotes the visualization of something that was either drawn, and remained unbuilt, or only imagined and described, as literary space is. From the fantastic places described by Jonathan Swift in Gulliver's Travels, published in 1726, pervaded by bitter social critique, to the dystopic institutions described by Franz Kafka in the early 1900s, literary architecture is a central piece of cultural heritage as are the images it has evoked over the centuries. Reconstructing the architecture described in a literary work is a way to investigate and illustrate the cultural and social context belonging to the artists as well as their ideas about it, especially in the case of fantastic places.

Here we briefly introduce the idea of literary architecture, the agency of description and the complex inter-media relationship between text and images, widely discussed in recent decades from Mitchell (1986) to Cometa (2012). Literary buildings described by Pliny the Elder, Jorge Luis Borges, and Umberto Eco are mentioned to illustrate 'adaptation' and 'reconstruction' as two different modalities of depicting architecture following a text. The participative and integrative role of the reader is also discussed. The process of reconstruction is then applied to the description of the Palace of Love and Venus from Giovan Battista Marino's Adone, published for the first time in Paris in 1623. After analysing the text, two different approaches - a geometrical approach and an iconographical one-are adopted and intertwined to both produce visual models and demonstrate the representational limits of literary architecture when it is based upon ineffable and unmeasurable space.

\section{The Figuration of Literary Architecture}

Writers use space as a setting for their characters' stories and description to communicate it to the readers. As explored by Juan Calatrava and Windried Nerdinger (2010), some authors actually designed rooms, palaces, districts or an entire city as a sort of cinematic set to develop their novels over the years. But the visual effect of a description is always a collaboration between the writer and the reader. Unless specific real places are mentioned or presented by pictures, as Eco (1980) did in his The Name of the Rose (Colonnese 2016), the reader autonomously produces mental images of it. Besides the point-of-view and other narrative strategies, the writer shapes three-dimensional reality into a narrative-oriented space, adapts it to the setting of the events, and summarizes it in the description. The readers receive it through the filter of their personal knowledge and experience, figuring it in their own mind. Somehow, the denotative agency of the spatial data explicitly provided by the writer intertwines with the connotative agency of the visual information projected by the readers onto the text itself. When denotation is prevalent, the text may look like 'instructions for use' or a technical report from an architectural project, whose writing is expected to avoid misunderstandings (and 
is generally easier to reconstruct). When connotation is prevalent, the text may resemble poetry, where each word is chosen to involve readers' feelings and moods (and is generally hard or impossible to reconstruct).

Moreover, literary architecture - that is, a set of places described in a literary work-is defined both by what is explicitly reported in the text, and by what is omitted for reasons of efficiency, speed, or economy but is autonomously and unknowingly added by the readers. What this means for us is that reconstructing a literary space depends strictly on the denotative component of the description and every autonomous contribution adopted in the reconstruction must be made consciously and transparently.

These aspects make the relationship between text and image, in particular between the description and the representation of the architectural form, complex and sensitive to the cyclic change of the 'gaze', here intended as a cultural and aesthetic device. The ekphrasis of a work of antiquity can be used to figure out the structure and decorations of buildings that have now disappeared but also to measure the difference in cultural and aesthetic values between distant ages and civilizations. Pliny's description of the Tomb of Porsenna in Chiusi in Book XXXVI of his Historia Naturalis evokes a structure that is magnificent and inconsistent as well, with its incredible jumble of pyramidal and spherical elements. The reconstructions attempted by Antonio da Sangallo, Baldassarre Peruzzi, Christopher Wren, Antoine Chrysostome Quatremère de Quincy and many other architects gave birth to different forms which indirectly resulted from the negotiation of different cultures and the need for a coherent arrangement. At the same time, this kind of 'translation' may result in new creations via misunderstandings or misappropriations as shown by the shapes inspired by the fantastic reconstructions and applied to real architecture (Colonnese 2015). Such attempts are also encouraged by the description itself, which initially evokes a clear structure based on simple geometry and proportions only to puzzle the reader later with a series of ambiguities as it moves to the top of the monument.

Similar strategies and topics are also frequent in the fiction. In 'The Library of Babel', included in his collection Ficciones, Jorge Luis Borges (2003) imagined a massive, mathematical structure, made up of hexagonal cells connected to each other. As noted by Sophie Psarra $(2009,89)$, “Borges' description of one hexagon is so detailed and clear that a drawing of the layout must have assisted the development of the ideas". The many depictions inspired by his description can be ascribed to either the category of 'adaptation' or that of 'reconstruction'. Adaptation is a form of trans-media transcription, a sort of 'free' translation aimed at transferring the meaning and effect of the place rather than its actual form. In contrast, a reconstruction is a 'literal' translation of literary architecture, which is based on the hypothesis that the writer had originally conceived a three-dimensionally coherent structure.

Examples of adaptation are found in the Babel library as drawn by the Italian artist Milo Manara (1981) in the graphic story Fone and in the illustrations of the French artist Érik Desmazières (1998), which deliberately 'betray' Borges' description. Instead, they borrow visual models from science fiction and Giovan Battista Piranesi's carceri to communicate the library's weird ambience and 
paradoxical contents. Since each medium responds to a different expressive and communicative system, any trans-media transcription implies a modification of some elements in order to preserve the primary meaning. This phenomenon can be appreciated in the library shown in the film adaptation of The Name of the Rose compared to its description in the book. While Umberto Eco had imagined, drawn and described it as a maze of polygonal rooms extending on a single level and even included its plan in the book, the scene designer Dante Ferretti translated it into a three-dimensional labyrinth inspired by Borges' hexagons (Colonnese 2016). The result is much more 'photogenic' and the implicit inconsistency between the interior and exterior polygons is camouflaged by the montage (Fig. 1).

Examples of reconstructions of Borges' library are found in the work of Cristina Grau, Antonio Toca-Fernandez, Carlo Casolo, William Bloch, Mauro Boffardi, Alex Warren, Lyn Rice and Astrid Lipka, Sophie Psarra (2009) and the author himself (Colonnese 2006), who implicitly assumed that Borges had described an actual building. They (we) first grappled with the ambiguities in the description of the cell present in the first version of the short novel, corrected by Borges himself, and then with the ambiguities related to the aggregation of the cells in three-dimensional space, which prevent a homogeneous distribution.

Conversely, Renato Giovannoli's (2015) persuasive reconstruction highlights the defects of Borges' description, and provides adequate corrections. In this way, Giovannoli identifies the ontological limits of the reconstruction process itself. Is it appropriate (and useful) to intervene on the text in order to obtain a correct and representable structure in the three dimensions, indirectly labelling the text as wrong? Or should we respect the limits of the description, according to the idea that literary space can resist and defy representation, such as certain incongruous engravings by Giovan Battista Piranesi?

\section{Giovan Battista Marino and the Palace of Love and Venus}

The poet Giovan Battista Marino (1569-1625) was born in Naples, where he lived and was educated and trained. In 1600, he joined the service of Cardinal Aldobrandini in Rome. Thanks to this, Marino had the opportunity to get in touch with artists and their works and to travel, visiting Siena, Florence, Bologna, Ferrara, Padua, and Venice. In 1606, he followed the Cardinal to his archbishopric of Ravenna, from which he visited Rimini, Parma, and Modena, before moving to Turin in 1608. In 1615, Marino moved to Paris, soon becoming a central figure at the court, and influencing the French literary and artistic entourage. Here, in 1623, he published Adone (Adonis), the longest poem of Italian literature, which would exert a great influence on depictions of mythological subjects (Fig. 2).

Adonis is a young hunter loved by Venus. Ignoring the goddess, who had warned him to hunt only small animals, he is killed by a boar. His story is told in the verses 710-739 of Book X of Ovid's Metamorphoses but many other stories are also told in Marino's poem through a wide range of metaphors and comparisons. Adonis includes the description of the Palace (or Castle) of Love and Venus, a novel embodiment of the Erotocastro, a chivalric romance topos (Ferrari 2007: 176). Its 

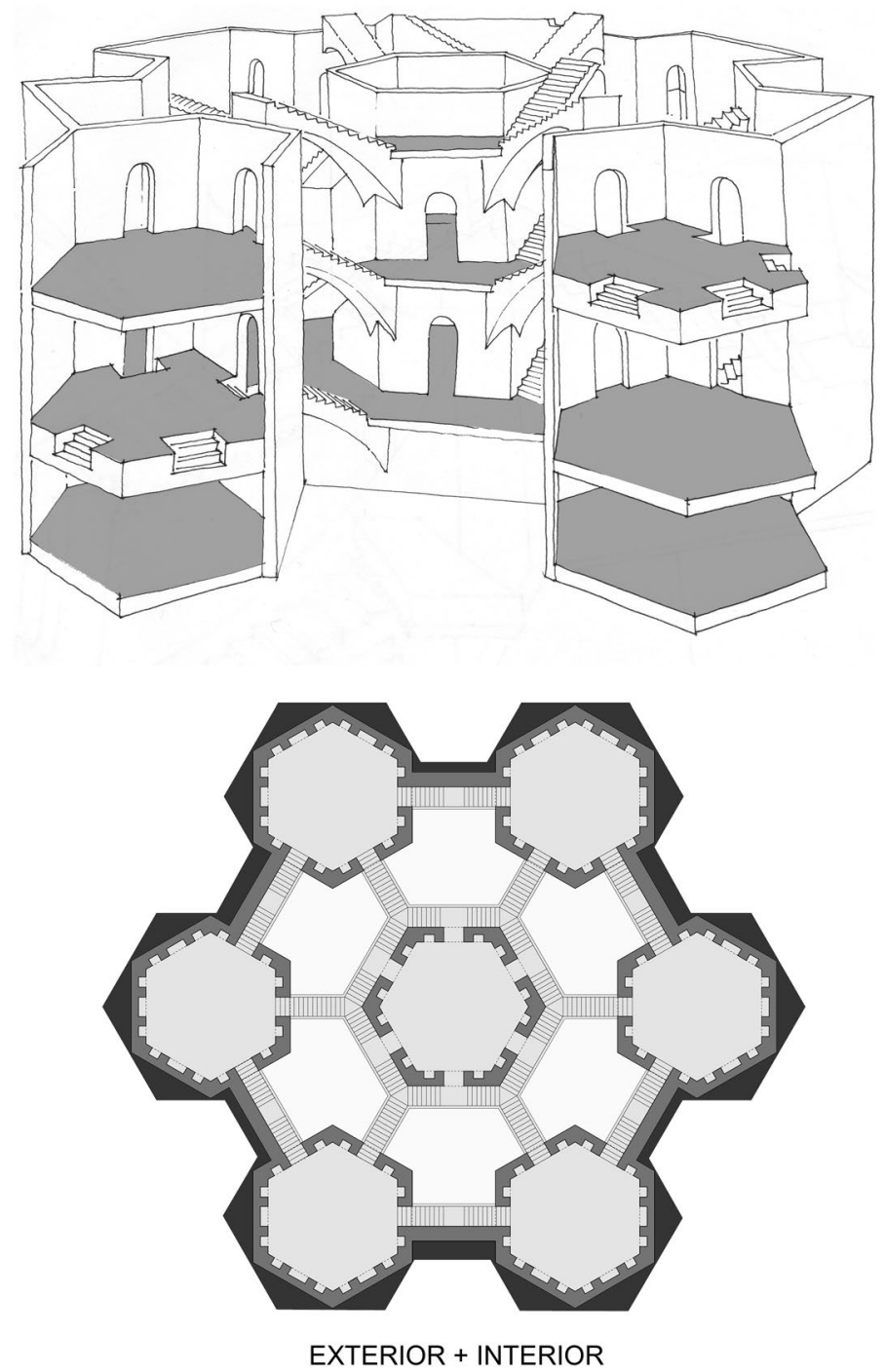

Fig. 1 (Above) Dante Ferretti's study model for the cinematic labyrinth for Jean Jacques Annaud's Name of the Rose (sketch by the author); below) reconstruction plan showing the inconsistency between the exterior envelope of the building and the interior form of the labyrinth

five towers represent the five human senses, with the central one, which is higher than the others, denoting the sense of touch. Although mostly allegorical, the description reveals shapes and materials drawn from a direct experience of ancient and Renaissance architecture.

In several cantos, blocks of lines are dedicated to the description of the palace. It is first mentioned in Canto II, when Marino compares it to a cage, a prison and a labyrinth and describes it in a sort of bird's eye view: 
Fig. 2 Frontispiece of the 1626 edition of Adone (Marino 1626)

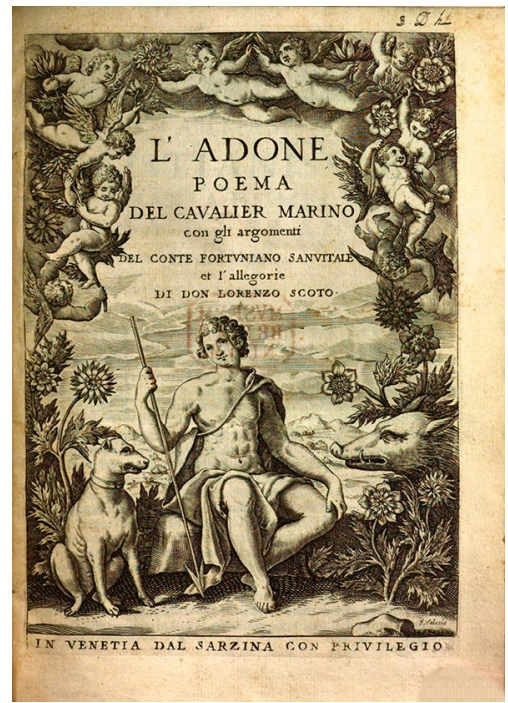

The palace rises, where the goddess resides / all of a wall adamantine and strong. / The great cloisters, the great balconies cast envy and scorn / at the loggias of the empyrean court. / It has four fronts and four sides around it, / four guard towers and four gates; / and planted in the middle another tower / which makes five the number to compose. / In its four corners almost like a compass / the towers are all placed equally. / The one in the middle is of the same stone, / but greater and more eminent than the others. / One is in front of the other and the way is opened / by more than one sublime and resplendent bridge, / and with art very beautiful and well distinguished / each of the four goes out to the fifth. / So high and slender is each arch / which stretches under each bridge, / that it seems that this sublime arching / by divine miracle hangs in the air. / The curvature of the passage of every bridge, / shines with many varied gems, / so that each arch is dressed with lights and colours, / resembling on earth a celestial iris. / The four towers built up in the corners / are made square and of equal size, / except the principal among all the others, / which is built in a round shape. / They are equally distant and conducted / are the lines in a row with delightful architecture, / and except for the largest that remains in the middle, / through each tower one arrives a garden. ${ }^{1}$

\footnotetext{
1 Marino, Adone, Canto II (Marino 1976: 32-33): Sorge il palagio, ov'ha la dea soggiorno / tutto d'un muro adamantino e forte. I I gran chiostri, i gran palchi invidia e scorno / fanno ale logge del'empirea corte. / Ha quattro fronti e quattro fianchi intorno, / quattro torri custodi e quattro porte; le piantata ha nel mezzo un'altra torre, / che vien di cinque il numero a comporre. / Ne' quattro angoli suoi quasi a compasso / poste le torri son tutte egualmente. / Quella di mezzo e del medesmo sasso, / ma del'altre maggiore e più eminente. / L'una al'altra risponde e s'apre il passo / per piu d'un ponte eccelso e risplendente, / e con arte assai bella e ben distinta / ciascuna dele quattro esce ala quinta. / Si alto e si sottile è ciascun arco / che sotto ciascun ponte si distende, / che ben si par che quel sublime incarco / per miracol divino in aria pende. / L'incurvatura, ond'ogni ponte ha varco, / di tante gemme variata splende, / ch'ogni arco ai lumi ed ai color che veste, / somiglia in terra un'iride celeste. / Le quattro torri insu $i$ canton costrutte / son fatte in quadro e son d'egual misura, / tranne la principal fra l'altre tutte, / ch'e
} 
The stone building stands on a hill. It has four fronts, four sides and four entrances. Four 'compass-like' square towers are placed in the corners and lead to as many gardens. A fifth tower, circular and prominent, is placed in the middle and is connected to the others by thin arched bridges covered with precious stones that make them look like rainbows. Statues, artworks, and precious materials abound and will progressively increase as the description goes on.

In Canto III, Marino takes Adonis' point of view as he enters one of the towers:

...checkered in quarters of white and vermilion. / Towering in the middle ample and sublime / rises a snail stair, where it descends and rests. / Four arches that come out from its top, / make a cross that rests on the balconies, / to which are conjoined the first rooms, / where one can drift from loggia to loggia, / since a stair embraces and commands / the entire palace through four corridors. / In the four corners around, where the courtyard / is partitioned, divided by the cross, / there, inlaid by a feverish stone carver / are four illustrious fountains, one on each side. ${ }^{2}$

Moving some plants off, Adonis finds himself inside a square courtyard with a red and white checkered floor. Here, he sees four fountains and a towering helical staircase in the middle, from which four arched bridges depart to lead to the loggias on different levels. Only in Canto V, he climbs up the staircase to the top, arriving at an immense room with one hundred windows and a figure representing the whole universe:

...twisted stairway / whose arches stretch from the middle of the courtyard, / the ivory steps that go up and down, / presses upwards and with beautiful Adonis ascends on high. / Here an immense hall, through a hundred windows, / of polished crystal, the day takes place / and in a beautiful depiction of gleaming mosaic / the figure contains the universe. / Through four doors opened to the four winds / one enters and all are of gold candid and polished. / It has four walls whose rich encrustations / conceal the view of the part below. ${ }^{3}$

\footnotetext{
Footnote 1 (continued)

fabricata in sferica figura. / Son distanti del pari e son condutte / le linee a fil con vaga architettura, / e salvo la maggior che'n grembo il tiene, / per ogni torre in un giardin si viene (our trans).

2 Marino, Adone, Canto III (Marino 1976: 84-85): ...scaccheggiato a quartier bianchi e vermigli. / Torreggiante nel mezzo ampia e sublime / sorge lumaca, onde si scende e poggia. / Quattr'archi, ch'escon fuor dele sue cime, / fanno una croce, ch'ai balcon s'appoggia, / a cui congiunte son le stanze prime, / onde scorrer si può di loggia in loggia, / sì ch'una scala abbraccia e signoreggia / per quattro corridoi tutta la reggia. / Ne' quattro quarti intorno, onde il cortile / dalla croce diviso si comparte, / havvi intagliate da scarpel febrile / quattro illustri fontane, una per parte (our trans).

3 Marino, Adone, Canto V (Marino 1976: 150-151): ...torta scala / che di mezzo al cortil gli archi distende, / gli eburnei gradi, onde si monta e cala, / preme e col bell'Adone in alto ascende. / Qui per cento finestre immensa sala / di polito cristallo il giorno prende / e in un bel quadro di mosaico terso / la figura contien del'universo. / Per quattro porte a quattro venti esposte / s'entra e tutte son d'or schietto e forbito. / Ha quattro mura le cui ricche croste / del fondo interior celano il sito (our trans).
} 
Finally, in Canto VI, Marino reveals that a garden is hidden in the centre of the palace, divided into five sectors connected by arcades and guarded doors, so that from each loggia, a different garden can be seen:

In the garden, divided into five porticoes, / five portals give entrance to the wayfarer / and by a sentinel seated on the threshold / the door of each portico is guarded. / One enters through every door into paradise / where a small garden expands, / so that each space is equal to the one near it / a single garden contains five gardens. / Five gardens the delightful palace / in her five towers included embraces, / so that from her balconies one can admire / a different a garden for each facade. / A bordering wall every garden shades, / which stretches out for a thousand braccia. / This is enclosed in a square and the middle leaves / doors, so that one garden passes into the other. / From each corner of the four projects outwards / corner tower at the tip, / and the fifth among them rises in the middle / so that beyond the wall its cornice appears; / and, as I said, in a straight line can be seen / tower from tower equally separated; / and with the right measure of graceful art, / I don't know how, frames every garden. ${ }^{4}$

Here appears the only measurement mentioned by Marino: 1000 braccia (the equivalent to about $670 \mathrm{~m}$ in case of Neapolitan braccia). This may refer to a wall that shades the garden or could concern the general perimeter of the castle or courtyard or even be, as suggested by Hubertus Günther (2016), only a hyperbole to indicate something very large. But the list of ambiguous elements is very long. Is there a circular tower or a garden in the centre of the building? What are the 'compass-like' towers like? How can a huge hall be at the top of the narrow staircase? How are the five inner gardens arranged? How can the castle pass from the 4-based geometry of the building to the 5-based arrangement of inner gardens?

\section{Stepping into the Reconstruction}

My brief summary of the many verses Marino dedicated to the palace obviously already provides the basis for an idea of reconstruction, even if a partial one. As a sentence can be translated only after understating its meaning, my summary of the description results from personal conjectures about its form. Therefore, any

\footnotetext{
${ }^{4}$ Marino, Adone, Canto VI (Marino 1976: 160): Nel'orto, in cinque portici diviso, / dan cinque porte al peregrin l'entrata / e da un custode insu la soglia assiso / la porta d'ogni portico e guardata. / S'entra per ogni porta in paradiso / la dove un giardinetto si dilata, / talche di spazio egual tra se vicini / contiene un sol giardin cinque giardini. / Cinque giardin la dilettosa reggia / nele sue cinque torri inclusi abbraccia, / siche da' suoi balcon lunge vagheggia / differente un giardin per ogni faccia. / Confine un muro ogni giardino ombreggia, / che stende linea infuor di mille braccia. / Questo in quadro si chiude $e$ in mezzo lassa / porte, onde l'un giardin nel'altro passa. / Ciascun canton de' quattro innanzi sporge / una torre angolare insu la punta, / e la quinta tra lor nel mezzo sorge / si ch'oltre il muro la cornice spunta; / e, come dissi, a dritto fil si scorge / torre da torre egualmente disgiunta; / e con giusta misura arte leggiadra, / non so come, ogni giardino inquadra (our trans).
} 
reconstruction begins from the analysis of the text and its 'rewriting'. This implies the definition of a first mental model which must satisfy as many conditions as possible and to highlight the ambiguities or gaps enunciated in the text. With a mathematical metaphor, it is a sort of equation of $n$-variables, which requires the insertion of constants to produce alternative solutions to be compared and analysed. In this sense, Marino's text constitutes the primary source for reading and understanding the literary architecture, while the architectures of his time-built, designed, or only 'written' architectures-are secondary sources that may orient the interpretation of the building elements.

Defining the mental model proceeds along two parallel tracks: the geometricproportional one and the historical-iconographic one. The former involves the definition of graphic models in plan and section after elementary geometries and proportions by progressive approximations; the latter follows the suggestions offered by the architectural precedents that Marino visited or could indirectly know through books or works of art.

For example, when considering the 'compass-like' towers, no other use of that term was found in coeval literature. It is assumed to indicate towers rotated $45^{\circ}$, which would be consistent with the octagonal perimeter ('four fronts and four sides'). Similar towers can be found in two castles that Marino might have seen in his travels.

One is the castle of the Princes of Acaja in Fossano, near Cuneo (Fig. 3, left): in the sixteenth century, Carlo Emanuele of Savoy and his wife Catherine of Habsburg had transformed it into a luxurious residence also by adding the two arched towers west of the loggias to the two already existing. The other is the castle of Mesola (Fig. 3, right). One of the nineteen delizie of the Este family, it was built between 1578 and 1583 by Giovan Battista Aleotti (1546-1636) after a project by Marco Antonio Pasi (1537-1599), known as Montagnana, on behalf of Alfonso II. Later, Aleotti re-proposed the same solution for the southern facade of the Rocca Nuova at Scandiano, datable to the first decade of the seventeenth century (Cuoghi 2003).

Beyond a certain level of complexity, developing the reconstructive mental model requires images, partial graphic models to illustrate and verify or reject the conjectures. In general, the castle is easy to figure as a square structure ('four fronts and four sides') with the corners cut to accommodate the four rotated towers and a large circular tower in the centre. This early figuration developed through freehand sketches and layouts (Figs. 4, 5), which served to acquaint me with elements and geometric relationships, but other visualization tools were also used, such as digital collage for the tower's courtyard.

According to Hubertus Günther (2016), this echoes the elegant helical staircase of Palazzo Contarini del Bovolo in Venice (in Venetian dialect a spiral stair is known as a bòvolo). The tower reconstruction was based on its actual size (almost $5 \mathrm{~m}$ wide; Dal Mas 1976: 46), and the need to have a loggia on five levels with an odd number of arches ( 9 for each side) to accommodate the four bridges (one for each floor) and the four fountains. The tower seen through Adonis's eyes was first explored through sketches (Fig. 6) and a digital collage (Fig. 7). The collage was based on a free-hand sketch and was mapped with elements copied from highdefinition photographs of Palazzo Contarini, in order to build the internal loggias. 

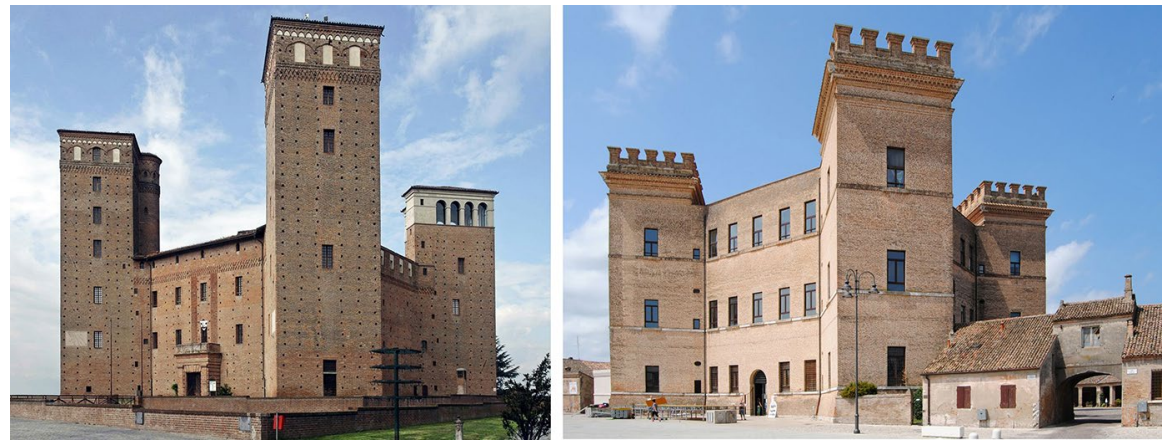

Fig. 3 (Left) the Castle of Princes of Acaja in Fossano, near Cuneo; (right) the Castle of Mesola

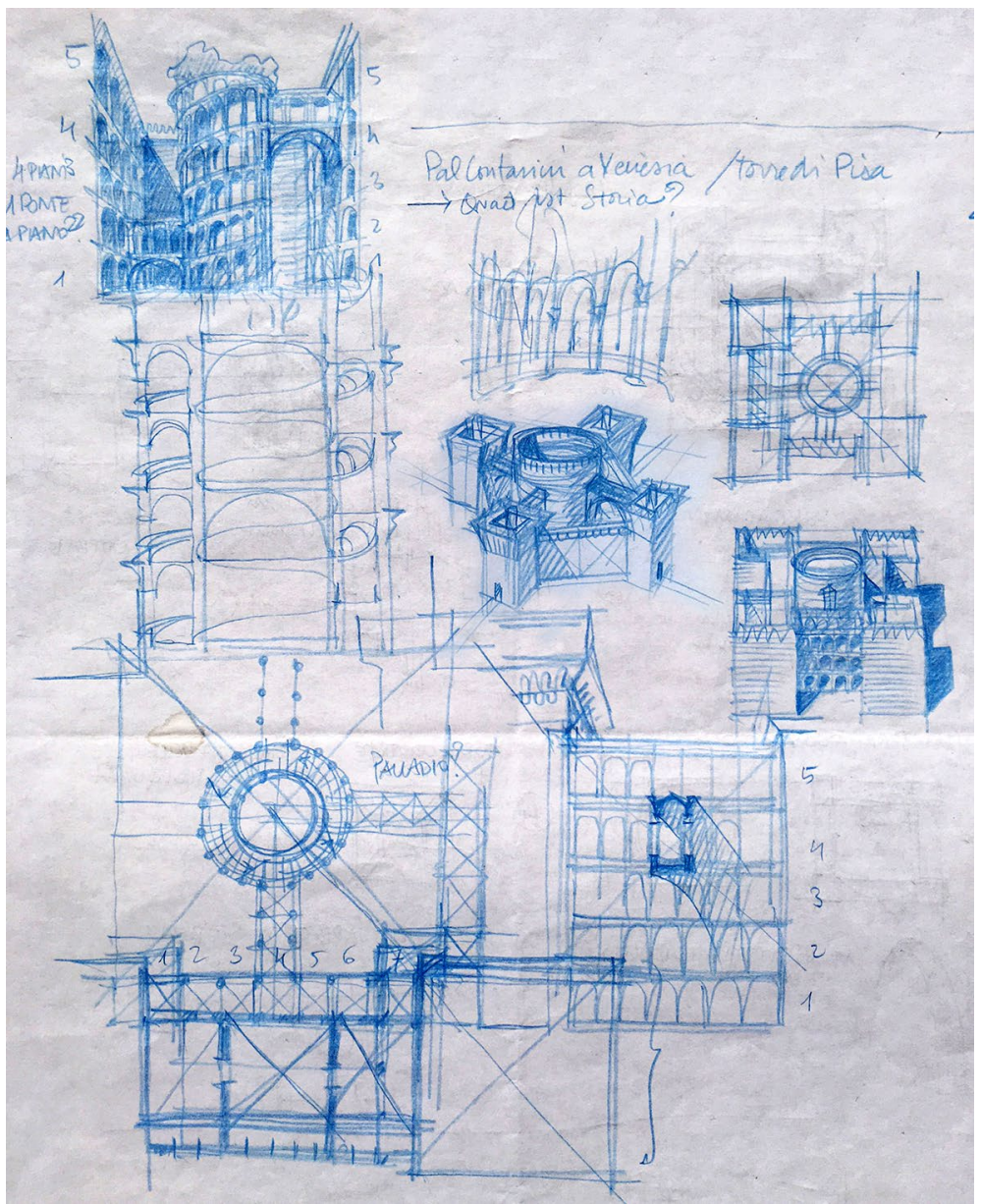

Fig. 4 Early explorative sketches after the description of the Castle of Love and Venus (drawing by the author) 


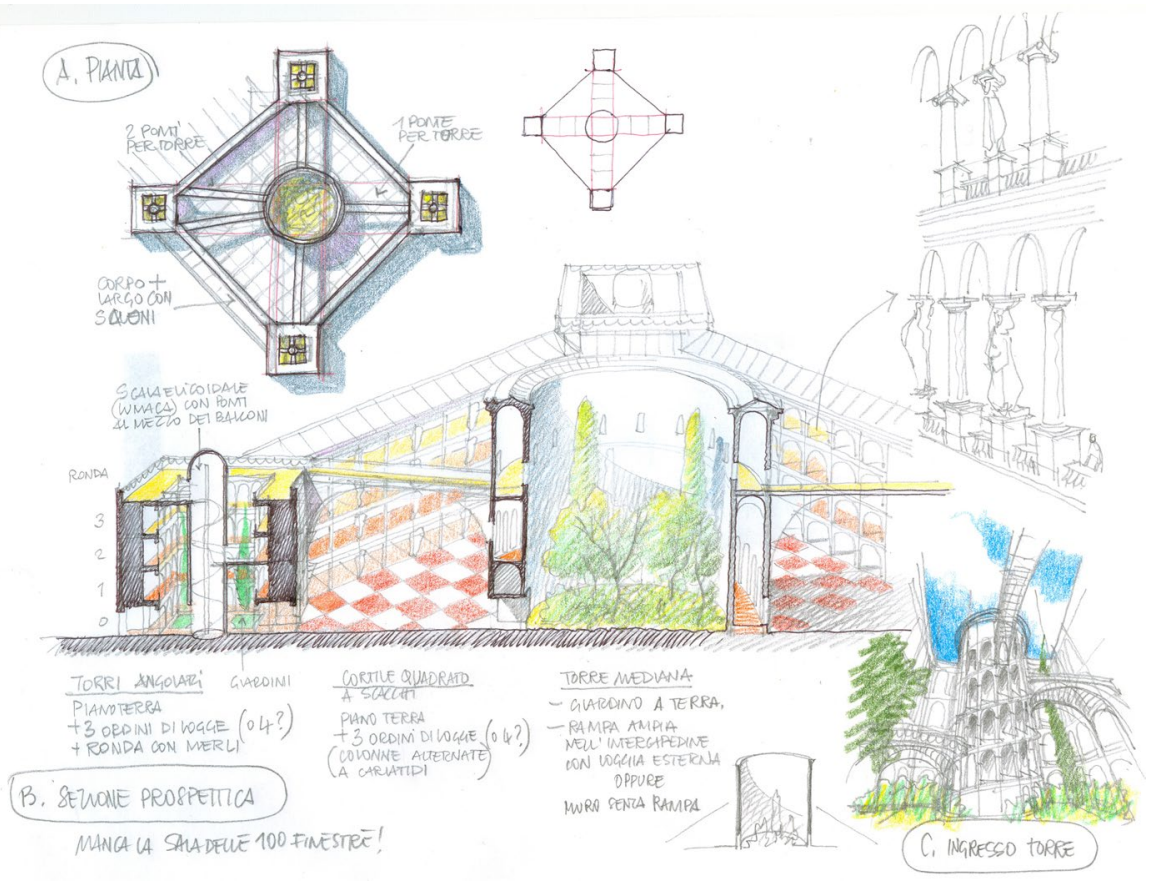

Fig. 5 Early explorative sketches after the description of the Castle of Love and Venus (drawing by the author)

The image of the staircase was placed in the centre of the courtyard. The ground floor of the staircase, which is partially missing, was digitally reconstructed. Four arched bridges made of bricks and stone and four geometric fountains were added around the staircase tower, whose checkered floor is composed of white Carrara and red Verona marble squares.

As a deliberate digital collage of existing pieces of architecture, this kind of picture may show a prevalence of the iconographic component over the geometric. The collage also reflects the criterion of accumulation which an artist like Marino used to assimilate architectural suggestions and to elaborate them in literary spaces; somehow, it also echoes the modalities of receiving Marino's description, the readers continually making use of their experiences to imagine a literary place. At the same time, it feeds further conjectures for the reconstruction process. A plan and section of the tower defined through the collage and the elements from Palazzo Contarini was exploited through CAD, in order to find the minimum size required to accommodate all the mentioned elements (Fig. 8). This size, which is 40 braccia (ca. $27 \mathrm{~m}$.) — 55 braccia (ca. $36 \mathrm{~m}$.) when adding a ring of rooms behind the loggia—was adopted to develop the general proportioning and dimensioning.

However, this is only a piece of the whole puzzle. Although Marino's description seems to follow a general-to-particular presentation of the castle, its proportional and dimensional definition is undefined, and the reconstruction process cannot follow the same criterion. Lacking explicit dimensions for the castle, simple proportional 

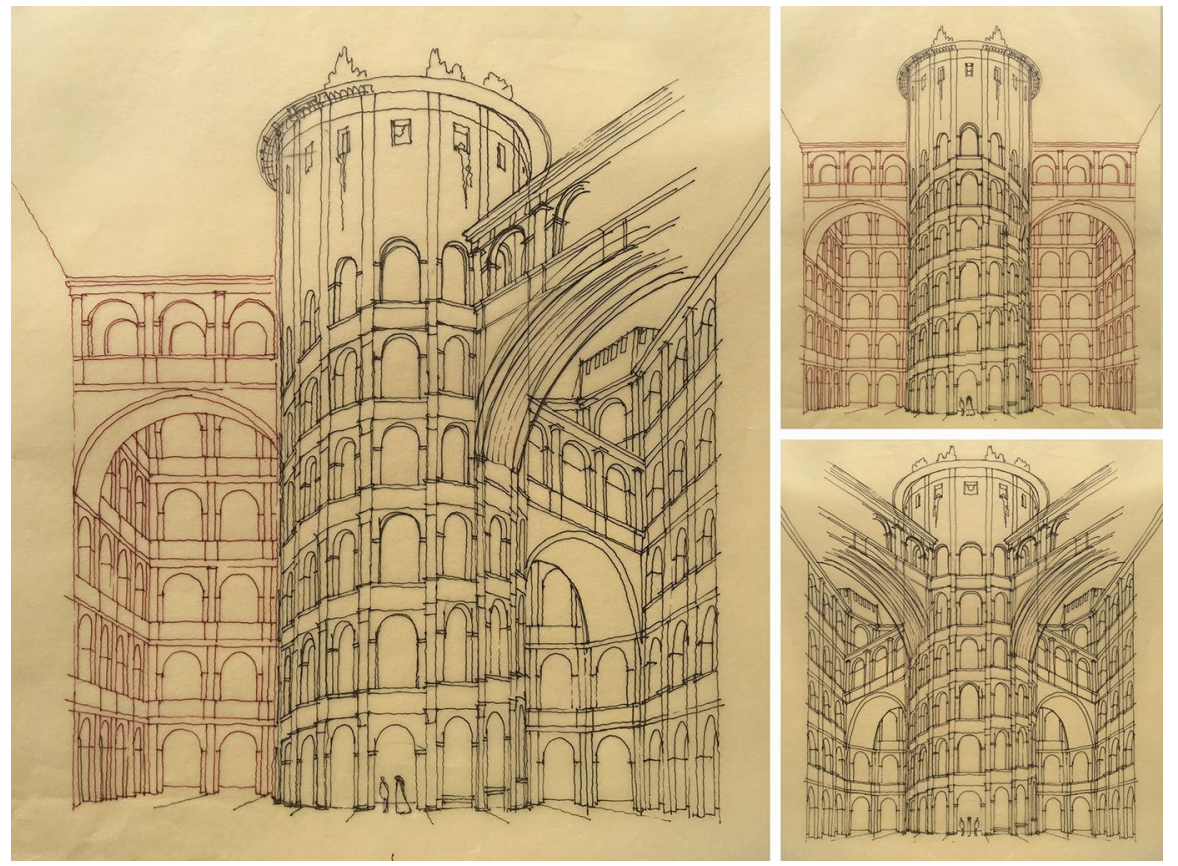

Fig. 6 Study drawing of the tower's courtyard and digital montage of alternative solutions for the bridges (drawing by the author)

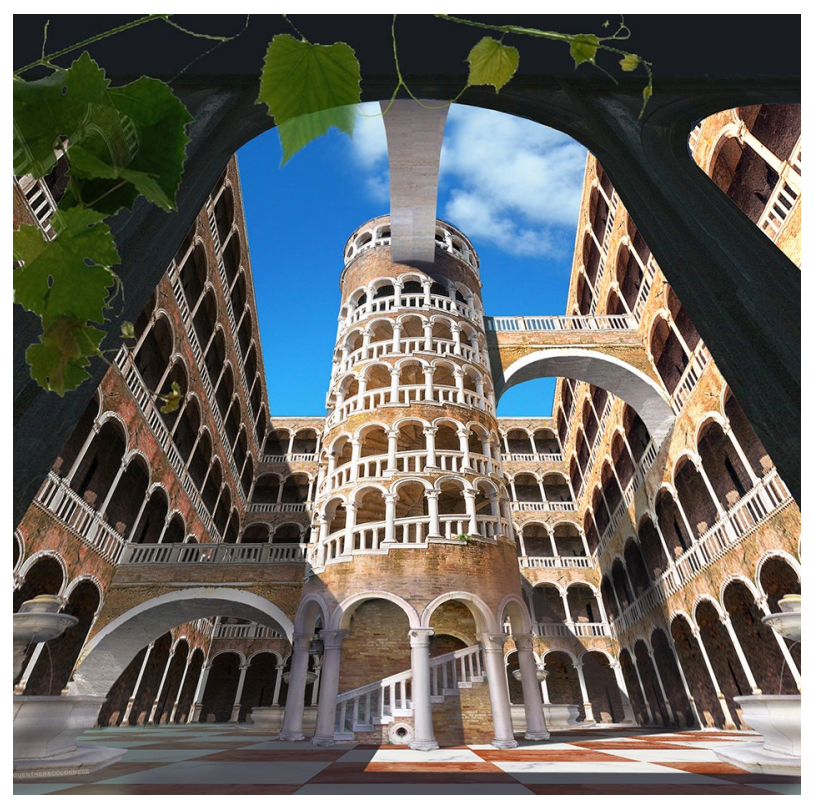

Fig. 7 Digital collage of the tower's courtyard after Palazzo Contarini (rendering by the author) 


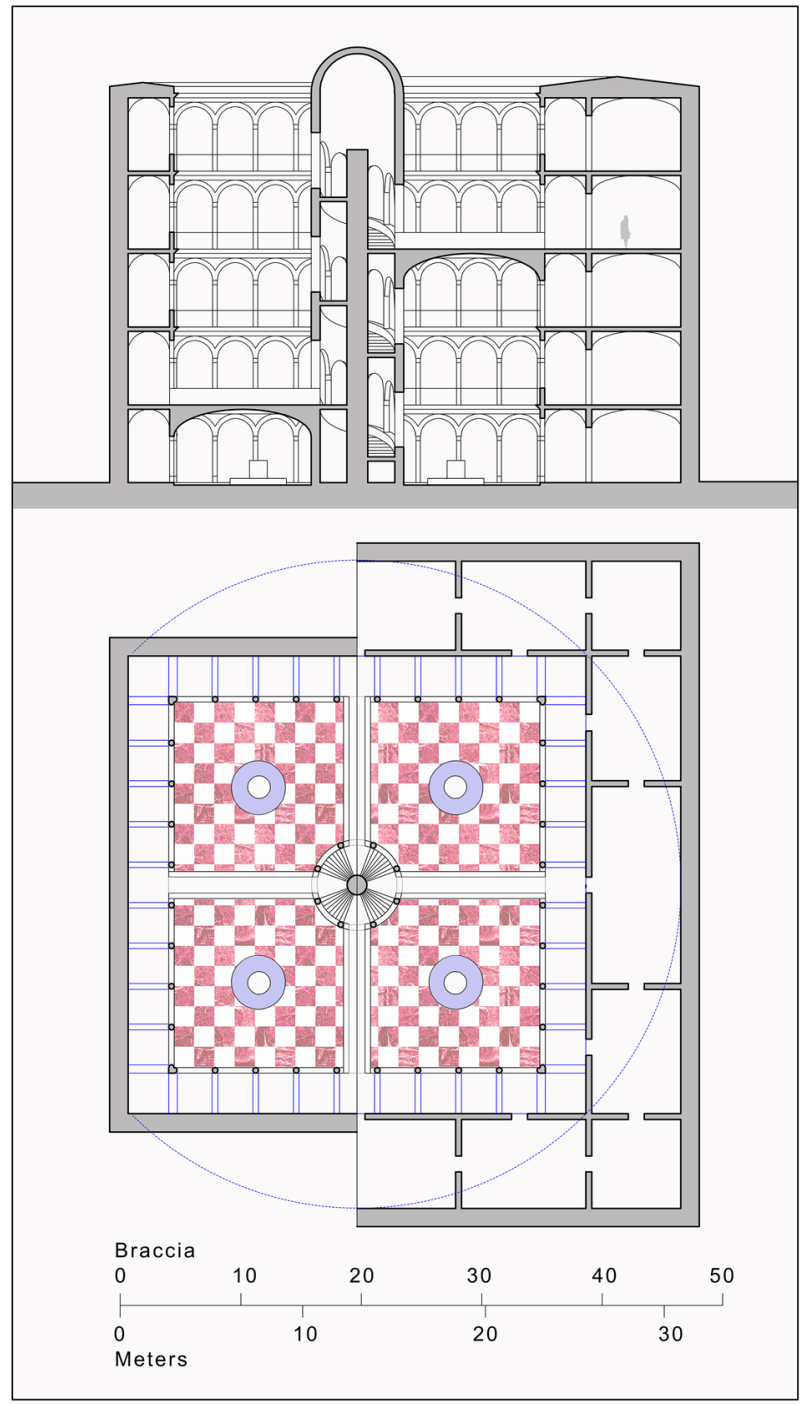

Fig. 8 Conjectural reconstruction of one of the corner towers in plan and section, comparing solutions with or without rooms behind the loggia (drawing by the author)

ratios between squares and circle were explored, by considering either different ratios between the tower's side and the side of the wall (Fig. 9a, b) or proportioning scheme based on recursive circles inscribed in square (Fig. 9c). The measurement of 1000 braccia was also considered as the length of either the whole perimeter or a single side (Fig. 9d). In this case, the minimum size required by the tower, approximated to 50 braccia, was used to test and comparing the resulting layouts.

In order to explore the spatial consequences of these conjectures and to simulate the effect of the loggia in the main courtyard, the layout in Fig. 8b was developed 


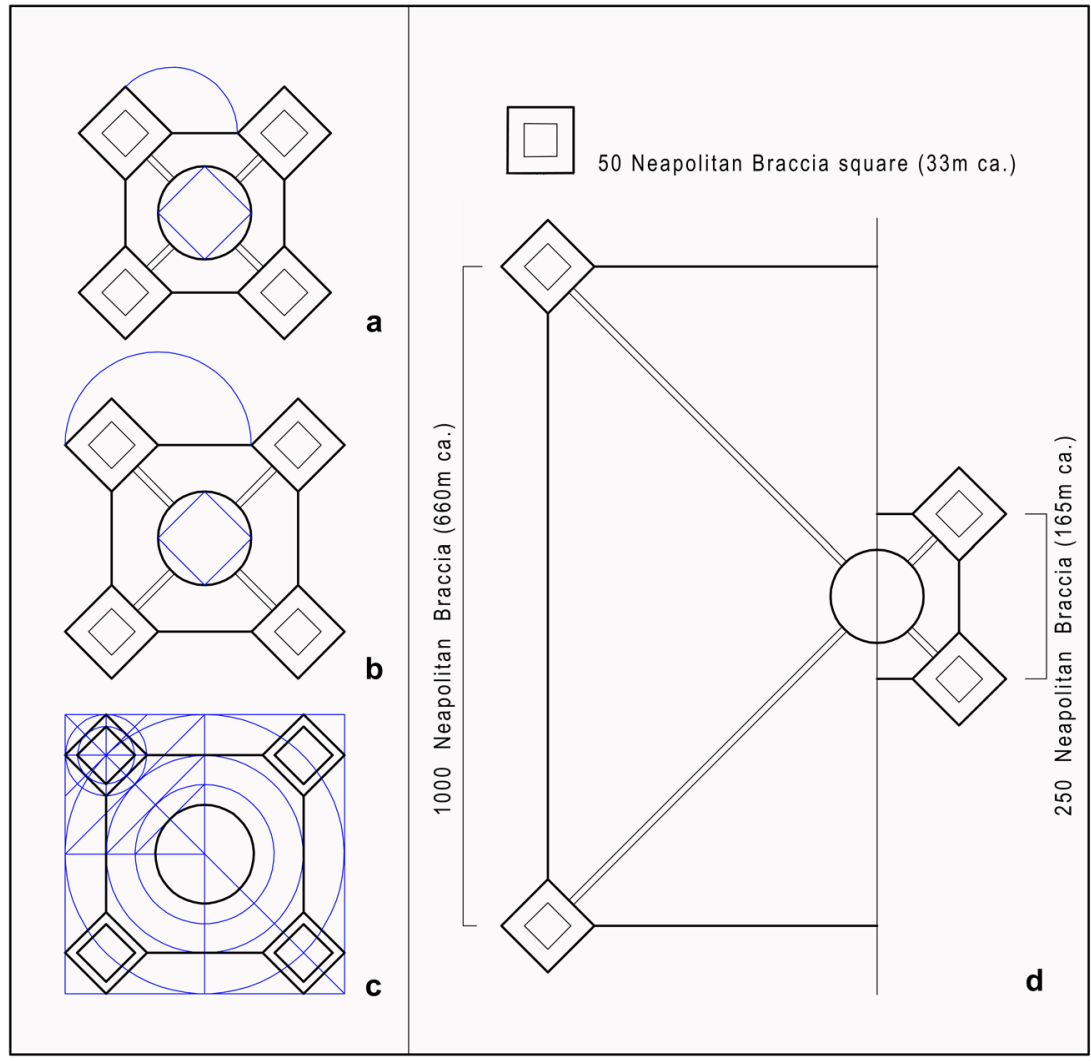

Fig. 9 Conjectural layouts of the Castle of Love and Venus based on proportions (left) and dimensions (right): a the castle's front is equal to the tower's side; b the castle's front is equal to tower's diagonal; c layout based on recursive circles inscribed in squares; $\mathbf{d}$ comparison between layouts considering the measure of 1000 Neapolitan braccia as either a single side or the entire perimeter of the castle (drawing by the author)

into a three-dimensional solid model (Fig. 10). The exterior walls were enlarged at the base to emphasize the feeling of a fortress. Larger towers were used, with the eleven arches of their loggias corresponding to the arches opening on the main courtyard. A larger staircase tower was inserted in order to have at least a small domed hall on the top of it, as expressed in the description. The gem-encrusted bridges connecting the corner towers to the central one were placed on the fifth floor, as Adonis climbs up the staircase to the top.

Despite these general conjectures, tests, and mock-ups, major criticalities emerge in the proportion of the towers, which look too 'horizontal', in the description of the circular room at the top of the staircase, and the organization of the gardens in the main courtyard, where the main circular tower is supposed to stand. The definition of the central tower is poor because Marino describes no specific element of it, rather focusing on the enigmatic garden. In general, as the focus shifts from the exterior to 


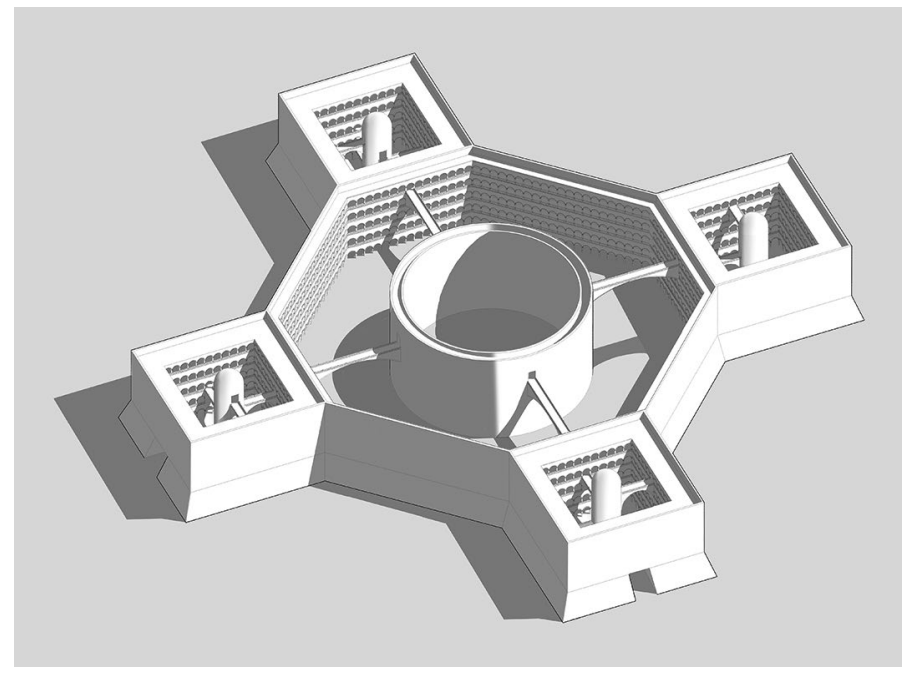

Fig. 10 Axonometric view after the digital model of the Castle of Love and Venus based on the layout $8 \mathrm{~b}$ (drawing by the author)

interior, the formal description of the castle becomes vague, uncertain, and a proper modelling is simply 'impossible'. Is it due to some mistake in the description, like Borges' library, or to a precise intention on the part of Marino?

\section{Discussion}

According to the philosopher Jacques Derrida (1979: 102), a work survives only if it is both translatable and untranslatable at the same time, as the work must necessarily lose a part of itself during the translation. In the case of Adone and its castle, much is being 'lost in translation'. The process of translating the castle's description into an exhaustive, coherent model revealed not only the ineffable quality of its space, which deceives a univocal, geometric representation, but also fundamental aspects of Marino's work and way of writing.

His early presentation of the castle, a sort of bird's (or god's) eye view, is geometric, synoptic, and descriptive. It provides the reader with a few clear elements about this sort of quincunx-shape building (Colonnese 2021), with four square towers and a round one in the centre. This seems to be the 'prototype' of the sixteenth century fortified palace as the readers could know it from their own experience. This early image becomes fixed in their minds and provides a basic structure onto which the following information can gradually lie and coagulate, as the inner parts of the palace unfolds through Adonis' gaze. While the exterior shows a stable configuration, step by step the interior reveals a metamorphic, magical nature. On the one hand, Marino confirms and articulates the architectural premises set out in the former description; on the other, he introduces minor contradictory elements involving the form and size of parts of the palace without questioning the 
general structure. In this way, he pursues a process of progressive spatial expansion, in which places previously described as limited turns out to be surprisingly larger and richer than they seemed. Like Harry Potter's magical camping tent, whose interior reveals itself to be as large as a house, the palace reveals itself as a collection of unpredictable and immeasurable spatial events, whose geometry is constantly on the border between allegory and reality. Occasionally, the palace description is left undefined, not to be completed by the readers' imagination but in fact to upset the expectations they developed on the first part of it. Marino welcomes the reason of his readers through simple elements and reference to existing buildings and gradually turn the architecture into a fantasmagoria of marvels and intangible sensations to catch them in his seductive web. Such a metamorphic quality of space is strictly connected with the mythological topics dealt with in the poem and is justified by the presence of Venus herself, capable of prodigious powers.

In the end, Marino's purpose is to amaze his readers as, according to his own words, meraviglia (marvel or wonder) is the ultimate goal of the poet. In this sense, his writing translates the fascination for the pictorial quadratura, perhaps appreciated with Baldassarre Peruzzi's Sala delle Prospettive in the Villa Farnesina in Rome; the early halls of mirrors; the sliding scenes in the theatre, presumably invented by Aleotti himself; and, above all, for the application of accelerated perspective, capable of virtually expanding the limits of walls.

His literary strategy works because he did not condense the description of the palace into a single canto, eventually highlighting the inconsistencies. He rather disseminated it across several cantos of his poem. Ideally following Adonis's point of view, the blocks of description are received almost as separate moments, without inspiring a search for coherence. Each block not only resize the general structure but also turns into an independent place, like a theatrical sequence of scenes (or a cinematographic montage). The first is the prototype of the early-Renaissance fortified palace, antecedent to the development of the bastioned fortress to face the cannons; the second is a palace courtyard with a detached staircase tower in the middle; the third is a huge round hall resembling the Vatican Gallery of Maps; the last is a garden divided into five parts, protected by a wall and shaded by arcades and pergolas, as can be seen, for example in many of Hans van de Vries' designs. Added to these, the several arched bridges mentioned by Marino allude to endless routes and relationships, expanding indefinitely the spatial and temporal dimensions of the castle. In this sense, Marino adopts a strategy that Umberto Eco (2012) named the vertigine della lista ('the infinity of lists'). Inspired by the prototype of the list of Greek ships in Homer's Iliad, it consists of enriching the description with lists of elements, ekphrases of architectural elements, works, and precious materials, which contribute to dissolve the architecture into the ambiance and to confuse and tire the readers, dampening their ability to control and criticize the literary architecture.

\section{Conclusion}

Erwin Panofsky once pointed out that Galileo Galilei had no objection to: 
fairies, dragons, hippogriffs and sorceresses, but was annoyed when he was asked to believe in a garden located in the middle of a palace ("one often sees palaces surrounded by gardens", he says, "but not contrariwise") yet containing "hills, valleys, woods, caves, rivers and swamps and all this junk on top of a high mountain" (Panofsky 2013: 13).

The Tuscan scientist seemed to be unhappy with the non-physical properties of literary space, where, unlike geography, the distance between two fixed points is not a stable value but may be 'changed' as the narrative requires. His words are a critique of chivalric literature but they also fit Marino's palace description in Adone. It is possible that he had tried to follow the spatial organization only to find himself lost and frustrated by the spatial inconsistencies?

While adaptation is expressly aimed at restoring the meaning and atmosphere of architecture in the context of the peculiarities of the medium and the work, as demonstrated by the case of The Name of the Rose, the practice of analysis, reconstruction and modelling after literary architecture involves an in-depth investigation on the form as well as the writers, their places, age, architectures they are supposed to know, etc. In this sense, it is based on a hypothetical spatial coherence that the writers, unless they describe existing places or write prefiguring future illustrations, rarely pursue. As in a translation, shaping a mental model that is as coherent as possible is necessary before proceeding with the reconstruction. Such a mental model has to be fed by contributions of different types and complexity. A first level is still verbal and consists in either rephrasing the description or writing just a summary of it. Free-hand sketching, which allows formal explorations and experiments, forms a second level. Digital collages involving the hypothetical precedents evoked by the writer form a third level. Two-dimensional CAD reconstructions useful to set the main proportions and dimensions form a fourth level and, incidentally, the limit of this specific case study. Without precise measure, three-dimensional modelling, the fifth level, is precluded, as are more sophisticated visual products based on it.

Spatial ambiguity is somehow consubstantial with Marino's artistic and literary project. The lack of specific measures collides with the mathematical nature of modelling, which is particularly stressed in the digital tools. Although applied, here three-dimensional solid modelling only provided conjectural results that simply demonstrate the arbitrariness needed to 'force' the data coming from actual description. In this sense, as a complete reconstruction is precluded, adaptations are possible and, somehow, implicitly promoted by the intertextual nature of the poem and largely used to achieve the partial results of this research.

While primary goals, in terms of models and iconographic products, are only partially achieved, secondary results emerge in the evidence of the linguistic strategies adopted-namely, the description separated in different chapters, the infinity of lists, the montage-like approach to literary space-and in the fluctuating size of space, in analogy with the then burgeoning Baroque taste for optical illusions. In this sense, this case study demonstrates that the agency of reconstructing and modelling literary architecture may provide a critical approach to text, a wide range knowledge, and visual tools to disseminate it. 
Acknowledgements I wish to thank Hubertus Günther for involving me in his studies and for triggering and addressing my graphical speculations on the Palace of Venus and Love, Lorenzo Grieco for his suggestion on translation, and Maurizio Ascani for his suggestions about the 'compass-like towers' and endless other 'ineffable' things.

Funding Open access funding provided by Università degli Studi di Roma La Sapienza within the CRUICARE Agreement.

Open Access This article is licensed under a Creative Commons Attribution 4.0 International License, which permits use, sharing, adaptation, distribution and reproduction in any medium or format, as long as you give appropriate credit to the original author(s) and the source, provide a link to the Creative Commons licence, and indicate if changes were made. The images or other third party material in this article are included in the article's Creative Commons licence, unless indicated otherwise in a credit line to the material. If material is not included in the article's Creative Commons licence and your intended use is not permitted by statutory regulation or exceeds the permitted use, you will need to obtain permission directly from the copyright holder. To view a copy of this licence, visit http://creativeco mmons.org/licenses/by/4.0/.

\section{References}

Borges, Jorge Luis. 2003. Finzioni. Milano: Adelphi

Calatrava, Juan, and Nerdinger, Winfried. 2010. Arquitectura escrita. Madrid: Círculo de Bellas Artes

Cameron, Fiona, and Kenderdine, Sarah (eds). (2007). Theorizing Digital Cultural Heritage: A Critical Discourse. Cambridge, MA: MIT Press

Colonnese, Fabio. 2006. Il labirinto e l'architetto. Roma: Kappa

Colonnese, Fabio. 2015. The Tomb of Porsenna. Textual and graphical translations of Pliny's Labyrinthus Italicus. In Traduire l'architecture: Texte et image, un passage vers la création, ed R. Carvais, V. Nègre, J.S. Cluzel, and J. Hernu-Bélaud, 161-172. Paris: Picard

Colonnese, Fabio. 2016. Ponti e scale nell'immaginario architettonico: la biblioteca-labirinto de 'Il Nome della Rosa' tra letteratura e cinema. In Ein Dialog der Künste. Das Verhältnis von innen und außen Beschreibungen von Architektur und Raumgestaltung in der Literatur der Frühen Neuzeit bis zur Gegenwart, ed B. von Orelli-Messerli and B. Kurmann-Schwarz, 32-39. Petersberg: Michael Imhof Verlag

Colonnese, Fabio. 2021. Mapping the Persistence and Evolution of the Quincunx. Nexus Network Journal 23, pp. 453-473

Cometa, Michele. 2012. La scrittura delle immagini. Milano: Raffaello Cortina Editore

Cuoghi, Diego. 2003. Giovan Battista Aleotti a Scandiano. In Giovan Battista Aleotti e l'Architettura, ed. C. Cavicchi, F. Ceccarelli, and R. Torlontano. Reggio Emilia: Edizioni Diabasis

Dal Mas, Mario. 1976. Giovanni Candi, architetto veneziano. Quaderni di Storia dell'Architettura, 127132 , pp. $27-54$

Derrida, Jacques. 1979. Living On: Border Lines, trans. J. Hulbert. In Deconstruction and Criticism. New York: Seabury Press

Desmazières, Érik. 1998. Onze estampes inspirées de Jorge Luis Borges 'La Biblioteca de Babel'. Paris: Aux dépens des artistes

Eco, Umberto. 1980. Il Nome della Rosa. Milano: Bompiani

Eco, Umberto. 2012. Vertigine della lista. Milano: Bompiani

Ferrari, Anna. 2007. Dizionario dei luoghi letterari immaginari. Milano, UTET

Giovannoli, Renato. 2015. Come costruire la Biblioteca di Babele a dispetto degli errori di Borges. Milano: Medusa edizioni

Günther, Hubertus. 2016. Phantastische Treppen, Brücken, Loggen von der Renaissance bis heute. In Ein Dialog der Künste. Das Verhältnis von innen und außen Beschreibungen von Architektur und Raumgestaltung in der Literatur der Frühen Neuzeit bis zur Gegenwart, ed Barbara von OrelliMesserli and Brigitte Kurmann-Schwarz, 15-32. Petersberg: Michael Imhof Verlag 
Kalay, Yehuda E., Kvan, Thomas, Affleck, Janice (eds). (2007). New heritage: New media and cultural heritage. London: Routledge

Manara, Milo. 1981. Fone. Métal Hurlant 1 (March 1981)

Marino, Giovan Battista. 1626. L'Adone: poema del Cavalier Marino con gli argomenti del Conte Fortuniano Sanvitale, et l'allegorie di Don Lorenzo Scoto. Venetia: Sarzina

Marino, Giovan Battista. 1976. Tutte le opere di Giovan Battista Marino, Vol. 2, I. Milano: Mondadori.

Mitchell, William John Thomas. 1986. Iconology: Image, Text, Ideology. Chicago: University of Chicago Press

Panofsky, Erwin. 2013. Galileo as a Critic of the Arts. Cham: Springer

Psarra, Sophie. 2009. Architecture and Narrative. The formation of space and cultural meaning. London: Routledge

Publisher's Note Springer Nature remains neutral with regard to jurisdictional claims in published maps and institutional affiliations.

Fabio Colonnese is an architect, Ph.D., and Research Fellow at Sapienza University of Rome, Italy, where he taught Descriptive Geometry, Architecture Survey, and Architecture Drawing. He took part to major survey campaigns, such as Castel Sant'Angelo, the Royal Palace of Caserta and several Rock-cut Monasteries in Cappadocia, Turkey. His Ph.D. research on the labyrinth and its manifold relationships with art, architecture, and city was published in Il Labirinto e l'Architetto (2006). While attending his Rome post-doc fellowship in Digital Survey and Representation of City, he focused on the relationship between the multisensorial experience of space and the image of architecture, as can be read in his book Movimento Percorsi Rappresentazione (2012). In the latest years, his articles and papers have focused mainly on perspective illusory devices in Baroque architecture, digital reconstruction after literary architectures, and architecture modeling. 